\title{
Painting in Poetry: A Stylistic Analysis of Ekphrastic Poems on Pieter Brueghel's Hunters in the Snow ${ }^{1}$
}

\author{
Sameh Saad Hassan*
}

\section{Introduction}

The main aim of this paper is to conduct a stylistic analysis of five ekphrastic poems: Walter de la Mare's "Brueghel's Winter," John Berryman's "Winter Landscape," William Carlos Williams's "The Hunters in the Snow," Anne Stevenson's "Brueghel's Snow" and Joseph Langland's "Hunters in the Snow: Brueghel," all inspired by Hunters in the Snow, a 1565 painting by Flemish artist Pieter Brueghel. The paper argues that these attempts to transform Brueghel's painting into words are not mere verbal accounts of their source of inspiration but rather poetic transformations of it in terms of meaning and style. Some of the main questions that this study attempts to answer are: How do the aforementioned poets employ the ekphrasis technique? What features of the painting does each poet foreground, background or even change? What is the poet's most central preoccupation? To give answers for these questions, a stylistic analysis of the poems will be conducted consecutively to highlight the similarities and differences between them and Brueghel's painting in terms of meaning and style.

Former studies of some of the poems at hand include David M. Wyatt (1977), Paul Boam and Hugo McCann (2001), and Jeffrey Meyers (2015). However, none of these studies employs stylistics to the analysis of the poems, nor brings together as many of the poems on Brueghel's painting as the present paper does. Though the significance of Wyatt's and Meyers's cannot be ignored, the two attempts are limited in their scale and scope to a discussion of "spatial order" in Williams's and Berryman's in the former and a rebuttal of Berryman's interpretation of "Winter Landscape" in the latter. Others like Boam and McCann, for example, started the discussion but did not give answers to essential questions about the relationship between the poems and the painting. They refer to three of the poems (Berryman's, Williams's and Stevenson's) in their discussion of poetry which engages with painting. Nevertheless, their passing discussion of these poems raises so many questions and provides no answers:

* Department of English Language and Literature, Faculty of Arts and Humanities, Suez Canal University. 
Each of the poets gives a different title to their poetic response to the same painting. Apart from indicating something of what they have particularly chosen to focus upon, one wonders what the titles reveal about each poet's approach to the painting. One wonders if Williams's and Berryman's poems could be really understood without a viewing of the painting. Brueghel's painting is so rich in detail that it allows one to focus on several frames within itself yet one wonders what, despite or indeed because of Brueghel's richness of detail, he has left out from the scene. (Boam \& McCann's "The Painter and the Poet")

Such enquiries and explorations about the relationship between poetry and painting have concerned writers through the centuries. For example, Plutarch attributed the quotation "Poema pictura loquens, pictura poema silens" to the Greek lyric poet Simonides of Keos to praise writers who used words and phrases, in the same manner artists used colour and design, so that readers could "see" the moments they were reading, "Simonides, however, calls painting inarticulate poetry and poetry articulate painting: for the actions which painters portray as taking place at the moment literature narrates and records after they have taken place" (501). Similarly, Horace established literature as an art form comparable to painting, "As is painting, so is poetry: some pieces will strike you more if you stand near, and some, if you are at a greater distance" (321). Horace meant that poetry deserves the same extensive analysis that painting requires. Arguably, Gotthold Ephraim Lessing emphasised that both arts are similar in the effect they produce, but "the arts themselves differ both in the objects and in the methods of their imitation" (ix). In other words, poetry and painting each has its own character and both differ in their subject matter and in their methods. In 1951, Wallace Stevens emphasised some common characteristics of poetry and painting, "No poet can have failed to recognize how often a detail, a propos or remark, in respect to painting, applies also to poetry" (The Necessary Angel 160). In Opus Posthumous, Stevens argues that, "To a large extent, the problems of poets are the problems of painters" (187). In this sense, painting provides an excellent source of inspiration for poetry.

Though poetry and painting represent two distinct genres of artistic creation, as Lessing once argued, both are inseparable and related to each other in a variety of ways. Sometimes, the painter and the poet are one and the same person, though "poet-painters are rare" (47) as observed by Osbert Sitwell. In many cases, however, poets and painters turn to one another for inspiration, as suggested by Stevens. The result in poetry is evident in the existence of an extensive literature of the "ekphrastic poem," defined by Peter Barry as "one which speaks to or of an art object, such as a painting, a statue, or a photograph" 
(155), a definition which highlights the verbal-visual, or rather word-image, interrelationship between poetry and visual arts. However, the main problem in the current discussion of the "ekphrastic poem" is how closely the adaptations (i.e. poetry) follows the original (i.e. painting) and what changes the poets make in the process of transformation.

To achieve its purpose, this paper will make use of key concepts of stylistics and stylistic analysis proposed by modern stylisticians such as Geoffrey Leech and Michael Short. Stylistics, which is, in its broadest sense, "the study of style" (Leech Language in Literature, 54), proves itself as an efficient tool in comparative analysis of the relations between poetry and painting. After all any piece of art, be it a poem or a painting, is in theory capable of being analysed in terms of style. The goal of the stylistic analysis of a work of art, in Mark Stansbury-O'Donnell's words, "is to associate or differentiate a work of art with or from others, creating stylistic categories on the basis of a specific set of visual qualities and object properties" (21). Likewise, the main aim of a stylistic analysis of a literary text is to give "a description of a literary text through a detailed linguistic analysis relating to meaning" (Krishnamurthy 50). Writing in 2010 about the use of stylistics in the study of ekphrastic poetry in particular, Berkan Ulu notes that "Stylistics and "ekphrasis" are seldom united and articulated together.... Therefore, the combination of ekphrastic poetry and stylistic analysis, as an interdisciplinary and extracurricular study, could provide insight for more comprehensive and resourceful studies" (39). Therefore, applying concepts and theories of stylistics, particularly those borrowed from art criticism such as foregrounding, would provide useful insights into the study of the ekphrasis technique.

One of the approaches of applying stylistic analysis to literary texts is "to apply the 'levels' model of language to the language of literature and investigate, in turn, everything from the phonology to the semantics of literary texts" (McIntyre and Jeffries 34). In addition to the study of different levels of language in the selected poems, the paper will make use of the theory of foregrounding. Leech notes that:

It [foregrounding] is certainly valuable, if not essential, for the study of poetic language. The norms of the language are in this dimension of analysis regarded as a 'background', against which features which are prominent because of their abnormality are placed in focus. In making choices which are not permissible in terms of the accepted code, the poet extends, or transcends, the normal communicative resources of the tongue. (Language in Literature 30) 
Foregrounding is one of the most important theories within stylistic analysis of any text. According to Short, there are two ways to produce foregrounding: deviation and parallelism. As noted by Short, "If a part of a poem is deviant, it becomes especially noticeable, or perceptually prominent" (11). He maintains that parallel structures in a text are equally important because "in addition to their perceptual prominence... they invite the reader to search for meaning connections between the parallel structures" (14). Therefore, the paper will focus on how the selected poets highlight (foreground) parts of the original painting which are especially important interpretatively by breaking the rules of language (i.e. deviation) or using particular linguistic structures more often than the readers would normally expect (i.e. parallelism). A stylistic analysis of the selected poems will attempt to reach clear conclusions as to how and why the poets foreground by means of language (e.g. graphology, phonology, syntax, lexis and semantics) some features of Brueghel's painting and ignore others, and what meanings and effects are associated with these foregroundings.

\section{Brueghel's Hunters in the Snow}

A stylistic analysis of poems inspired by Hunters in the Snow is likely to start with a discussion of the cultural background and stylistic aspects of Brueghel's painting. Hunters in the Snow is commonly known as an example of the Dutch and Flemish Renaissance painting response in the 16th century to Italian Renaissance painting. This is how the painting is described by Fred S. Kleiner who used it as the cover art of his book Gardner's Art through the Ages: Renaissance and Baroque:

Like many of his contemporaries, Brueghel produced landscape paintings, and Hunters in the Snow is his finest. It is one of a series of six paintings that Brueghel produced for the home of Nicolaes Jonghelinck, a wealthy Antwerp merchant. The paintings illustrate seasonal changes, with each of the panels representing a pair of months. This one is the December/January panel and shows the Netherlands locked in the particularly severe cold of the winter of 1565 . (vi)

As the painting depicts the "weary hunters" who "return with their hounds" from a hunting expedition in the winter landscape of the Netherland, the title of the painting, "Hunters in the Snow," refers to this event as well. In the painting, the three hunters accompanied by their dogs are in the left foreground. Along with a number of bare trees, the weary hunters and the dogs at the top of the hill take up almost one third of the scene and are all the dimmest objects in the painting, coloured in dark browns and greys against a white-filled background. All the 
other elements in the painting are more or less behind, either in the mid-ground such as the women and child who tend the fire in front of the tavern or in the distant background such as landscapes including the valley, the houses, the river, the frozen lake and mountain peaks. Still in the background, as John Malam observed, "In the distance, people are skating on frozen ponds. Some are playing ice hockey, while others are spinning tops" (16). According to Polyxeni Potter, "Hunters in the Snow was created during a frigid period known as the Little Ice Age, the second part of the $16^{\text {th }}$ century" (61). Thus, the 1560 s was a time of the so-called "Little Ice Age" and as shown in the painting, the water is frozen, the land is snow-covered, the trees are leafless, and the exhausted hunters return with the corpse of one fox which illustrates the paucity of the hunt.

However, the movement of the hunters in the painting going downhill to the valley is actually a movement from the foreground to the background, which gives the painting its depth as Helen Gardner describes it:

A clearly enunciated diagonal movement, marked by dogs and hunters, and trees, starts from the lower left-hand corner and continues, less definitely but none the less surely, by the road, the row of small trees, and the church far across the valley to the jutting crags of the hills. This movement is countered by an opposing diagonal from the lower right, marked by the edge of the snow-covered hill and repeated again and again in details. (450)

That is to say, the weary hunters will appear, in a moment subsequent to the one captured by Brueghel, very small and unimportant like the other villagers skating on the frozen lake in the background. As Richard Galligan noted, "The hunters are walking away from us as viewers, taking our eyes with them toward to the remaining two thirds of the painting. The hunters are simply starting points that lead us deeper into a more complex and life-affirming painting" (61). Indeed, the structure of the painting reinforces Galligan's interpretation that the painting is not really about hunters at all, but about "outsiders - neither glorified nor denounced - on the fringe of society" (61). The movement of the hunters towards the remaining two thirds of the painting shifts attention to the attempt of the townspeople to keep themselves warm and lively in winter and snow. Moreover, the fact that the weary hunters are in the foreground and all other elements including the ice skaters are in the background appears to determine the way in which Brueghel made this shift from the foreground figures to the large snowcovered scene in the background. In the title of the painting, "Hunters in the Snow," the headword of the title is "Hunters," and so it is the most prominent element in the title as in the painting. The prepositional phrase in the title, "in 
the snow," which acts as a modifier to the head noun emphasises that the painting does not show the men in the act of hunting. Instead, it shows them walking in the heavy snow towards their village. So the title puts the weary hunters in the foreground and at the same time it emphasises the presence of signs of winter in the background.

\section{De la Mare's "Brueghel's Winter"}

Written in the early years of the twentieth century, Walter de la Mare's poem, "Brueghel's Winter," could reflect what critics I. A. Richards, F. R. Leavis and Randall Jarrell described as a sort of escapism from the real world into unreal one in most of the poems by the poet. However, Henry Charles Duffin defends the poet arguing that "Is it any wonder if de la Mare, his soul aching for perfection, turns his back on the appalling mess 'that man has made of man', turns to contemplate the supreme loveliness of the world of spirits? There are critics of narrow vision who call this escapism" (126). Duffin's words draw attention to the fact that de la Mare's poems should not be stripped off their meanings under the charges of escapism.

Stylistically, the title of de la Mare's poem, "Brueghel's Winter," gives the reader a key to the poem. Although the painting depicts hunters in the snow and its title refers to that event as well, the hunters are backgrounded in de la Mare's poem. In the painting the hunters are in the foreground taking up a large portion of the scene and are the dimmest object in the painting against the white snow in the background. Although the return from the hunt is the most important thing in the painting, it is being played down in the poem via de la Mare's manipulation of foreground and background, as if it is less important than the image of winter in the background. It is like the poet is encouraging the reader to search for the deeper meaning in the scene. Also, if one looks at the titles of the painting and the poem grammatically, "Hunters" is the most salient word in the noun phrase title of the painting, but the most salient word in the title of the poem is "Winter" and "Brueghel's" only acts as a possessive pre-modifier. So the title also puts the painter in a more backgrounded position.

Starting from the background of Brueghel's painting, the poet uses lexical parallelism based on the use of lots of adjectives (e.g. Jagged mountain peaks, skies ice-green, cold scene, ink-black shapes, gabled tavern, naked trees, sinister spears, frozen sea, infinite line, etc.). It is also important to note that most of the adjectives used in the poem are negative (e.g. Jagged, cold, ink-black, sinister, frozen and subtle). One can infer from the use of negative and critical adjectives more often than the readers would normally expect that the poet's attitude towards the scene is rather negative. De la Mare depicts an image of a dark, 
gloomy atmosphere. Even the people skating on the frozen lake are described by the poet as "ink-black shapes" void of life and human liveliness.

Despite the fact that the poem itself makes no explicit reference to the painting, the poem is filled with details such as placement of objects and people as well as scenery and thus it succeeds to capture the identity of Brueghel's painting. By means of listing and lexical parallelism, the poet is able to introduce most of the elements depicted in the painting:

Jagg'd mountain peaks and skies ice-green

Wall in the wild, cold scene below.

Churches, farms, bare copse, the sea

In freezing quiet of winter show;

Where ink-black shapes on fields in flood

Curling, skating, and sliding go.

To left, a gabled tavern; a blaze;

Peasants; a watching child; and lo,

Muffled, mute--beneath naked trees. (de la Mare 59)

The vocabulary of the poem is not complicated, but it is reflects the use of an archaic poetic diction (Jagg'd, copse, gabled tavern, lo, etc.) which all along with the Gothic architecture of the tavern suggests a dream-like mysterious scene.

The acoustic aspects of the poem are an essential part of the poet's verbalization of the scene in the painting. The silent aspect of the scene is formed by phonological parallelism in the alliteration between "Muffled" and "mute" by the repetition of the bilabial consonant $/ \mathrm{m} /$. The poem is made up of two stanzas with a strict alternate rhyme scheme. The first is a fourteen-line stanza in which the second line rhymes with the fourth line, the sixth line, the eighth line etc. The second is a six-line stanza in which the second line rhymes with the fourth line and the sixth line. Although the poem reflects a deviation from the typical sonnet style, it has a similar structure to a Petrarchan sonnet because of a typical turn of thought between the two stanzas, like that of an octave and sestet. The descriptions in the first stanza provide the context for the poet's comment in the second stanza. The overall meaning of the poem lies in the second stanza in which the poet declares that none of the things he described throughout the poem would help someone looking at the same scene to solve life's mystery:

But flame, nor ice, nor piercing rock,

Nor silence, as of a frozen sea,

Nor that slant inward infinite line 
Of signboard, bird, and hill, and tree,

Give more than subtle hint of him

Who squandered here life's mystery. (de la Mare 59)

The first line in the second stanza, called the "turn" or "volta," signals a change in the tone or mood of the poem, which is typical of a sonnet. The last line indicates a departure from the wintery scene in Brueghel's painting to indulge in an undefined sense of mystery, emphasized by the use of lexical repetition of the word "nor," implying a sort of nonspecific transcendent reality or a spiritual quest that is wholly independent of the material universe portrayed in the painting. However, the way de la Mare depicts the event in Brueghel's painting is typical of his style:

The trick of revealing the ordinary in whimsical colours, of catching the commonplace off its guard, is the first of de la Mare's two chief gifts. The second gift is the sense of the supernatural, of the fantastic other-world that lies on the edges of our consciousness. (Untermeyer 415)

Thus, de la Mare predicts a moment in the future of the reader/spectator who shall see the depicted scene, by the eye of the mind or the eye of the head, and shall get nothing but a "subtle hint" in the attempt to unravel life's mystery. The poet ends his poem in mystery giving no answer, no indication or advice to the reader because in writing about the scene depicted in Brueghel's painting he spent his time trying to understand life's mystery, but it was no use. Still, the poem provides a new angel of approach for the original painting.

\section{Berryman's "Winter Landscape"}

John Berryman's poetic response to Brueghel's painting first appeared in1940. Here, the fact that Berryman's poem was written at the beginning of WWII (1939-1945) cannot be overlooked. Berryman himself argued that the poem is a reaction against the hysterical political atmosphere of the period "So far as I can make out, it is a war poem, of an unusual negative kind" ("One Answer to a Question" 325). In other words, the poem becomes a recontextualisation of the event in the painting to reflect a period in the twentieth century similar to that period of severe political and religious conflict in which Brueghel lived, "Bruegel's era was of course a period of great conflict and religious and political division caused by the advance of the Protestant Reformation and its conflict with the Catholic Church" (Zagorin 74).

Berryman starts his poem with a detailed description of the foreground of Brueghel's painting and then moves to the background: 
The three men coming down the winter hill

In brown, with tall poles and a pack of hounds

At heel, through the arrangement of the trees,

Past the five figures at the burning straw,

Returning cold and silent to their town. (Berryman 3)

It seems clear then that the main focus of Berryman's poem, though named as "Winter Landscape," is on the return from the hunt rather than the landscape. The presence of the hunters is felt in the five stanzas of Berryman's poem as "The three men," "they," "these men," and "this particular three in brown," but never as "hunters." The fact that the words "hunt" or "hunters" are not mentioned at all in Berryman's poem does not cut the links between the poem and Brueghel's painting for everything else depicted in the poem proves that the poem is a representation of the winter scene depicted in the painting. Instead, Berryman's poem shifts interest from the hunt to the result. That the men in the poem are "returning cold and silent to their town" indicates that whatever they had been doing was not successful and after they reach their town, they "will keep the scene" and say "What place, what time, what morning occasion/Sent them into the wood."

Throughout the poem, Berryman is more interested in the experience of weariness and defeat portrayed in the painting rather than the painting itself. As Meyers put it, Berryman may have intentionally deviated from the actual details of the painting to avoid an exact equivalence:

He [Berryman] distanced himself from the picture by calling his poem "Winter Landscape" rather than "Hunters in the Snow." The weary hunters - one dressed in green (not brown) - ignore the four adults and one child around the fire, whose smoke and flames shoot up dangerously toward the house. Two of the hunters appear between the stark verticals of the brown tree trunks (the third man is parallel to the trunk), which provide a sharp structural contrast to the frozen horizontal ponds. The hunters carry spears to kill (not poles to carry) their prey; the ladders are on the roof of the burning chimney (not on the church). (473)

Indeed, Berryman's poem includes no explicit references to Brueghel. Even the poem's title, "Winter Landscape," gives the sense that what is being described in the poem is an external landscape rather than a lifeless, motionless winter scene captured in a painting. This assumption is verified by the extensive use of the progressive form like "coming down," "burning," and "returning," which 
occurs only with dynamic verbs that usually show qualities capable of change as opposed to stative verbs. The future form is equally significant in Berryman's poem. It appears in the third stanza which is, syntactically speaking, the predicate of the subject "The three men coming down the winter hill" in the first line of the first stanza:

Are not aware that in the sandy time

To come, the evil waste of history

Outstretched, they will be seen upon the brow

Of that same hill: when all their company

Will have been irrecoverably lost. (Berryman 3)

As explained by the poet, the poem "is mounted in five five-line stanzas, unrhymed, all one sentence. (I admit there is a colon near the middle of the third stanza)" ("One Answer to a Question" 324). Thus, to preserve the integrity of the painting and the unity of the single moment depicted in the painting, the poet wrote the whole poem as one sentence with shifting parallel phrases and clauses. This one-sentence structure is stylistically different from one-line poems other lengthy poems without punctuation. The poem can be semantically divided in two parts. In the first part, the poet is describing the scene depicted in the painting, and in the second part he is reflecting about the future of the scene. The use of the future form in the centre of the third stanza" "Outstretched, they will be seen upon the brow" allows Berryman to depart from the present moment and predict a moment of the "time to come" that is not captured in Brueghel's painting. However, speaking about the future moment that has not arrived does nothing but highlighting the present moment (the beginning of WWII). Despite the fact that Berryman uses a different style that depends on the use of dynamic verbs, progressive forms, and future forms, the poem as noted by Wyatt seems to convey the same sense of timelessness in Brueghel's painting:

While such devices can act as the ground for sequential development, they can also suspend their typical forwardness through effects of repetition. The poem calls attention to this timelessness in no uncertain terms through thrice repeating the very words descriptive of repetition itself. "Returning," "Returning," "return": upon these three words progress through the poem turns, and halts. (257)

Similarly, Meyers argues that "since there is no manifest danger in either the painting or the poem, the claim in his [Berryman's] essay to a profound theme, which he "refuses to say" or even suggest, is not convincing" (475). He maintains that "the dominant theme, which Berryman clearly expresses in the third stanza, 
is the familiar poetic idea of ars longa, vita brevis (the Latin version of a Greek aphorism by Hippocrates): the Classical belief that art transcends time and that the painting will last when the people portrayed in it are dead" (475). In this sense, Meyers refutes Berryman's argument about a violent world, impending disaster or plunge into war. Berryman obviously painted with words a moment in time. In doing so, however, the poet distanced himself from the meaning of the original source of inspiration as well as the historical events taking place in the Dutch and Flemish Renaissance. The poem becomes Berryman's own description of an unchanging winter scene which emphasises a different reality from the one portrayed earlier by Brueghel. As such, the poem is neither a verbal equivalent to the picture nor an interpretation of it. It is nothing but the poet's reaction to that moment of history when the world rushed again into a war that would sooner or later become, in the poet's words, "the evil waste of history".

\section{Langland's "Hunters in the Snow: Brueghel"}

In 49 lines, Joseph Langland presents his poetic response to Brueghel's painting. Langland's "Hunters in the Snow: Brueghel" was published in his first book of poems, The Green Town (1956), and republished in Selected Poems (1992). The poem reflects the poet's interest in the Flemish painter. With regard to the choice of Breughel's painting as a source of inspiration for Langland's poem, it should be noted that Langland "began service in the U.S. Army as an infantry soldier and officer in the allied campaigns in France and Germany during World War II. Captain Langland served in the Allied military government of Bavaria from 1945 to March 1946" (Greasley 308). It is during that time in Europe that Langland knew a lot about Breughel and contemplated several of his paintings.

The poem opens with a description of the hunters and their hounds. What is really evident in such description is that Langland is using a style with lots of adjectives to draw an image full of much of the details of Brueghel's wintery scene:

Quail and rabbit hunters with tawny hounds,

Shadowless, out of late afternoon

Trudge toward the neutral evening of indeterminate form

Done with their blood-annunciated day

Public dogs and all the passionless mongrels

Through deep snow

Trail their deliberate masters

Descending from the upper village home in lovering light. 
Sooty lamps

Glow in the stone-carved kitchens. (Langland 98)

In a poem of approximately 296 words, the poet uses almost 42 adjectives (e.g. tawny, shadowless, neutral, passionless, etc.), 8 compound adjectives (e.g. blood-annunciated, stone-carved), and 7 noun adjuncts (e.g. rabbit hunters) which results in sophisticated stanzas full of details in the painting that the viewer of the painting might overlook such as "sooty lamps" and "stone-carved kitchens." The poem, however, is written in conventional syntax that maintains clear relations between thought and language.

There is something threatening in Langland's description of the late afternoon with its fading light and indeterminate form. As they move towards their home village, the hunters walk slowly and with heavy steps, typically because of exhaustion and harsh conditions. The fourth line, "Done with their bloodannunciated day," can be interpreted as a subtle reference to the poet's military memories when he served in the U.S. Army during World War II. The hunters are accompanied by dogs described by the poet as "tawny hounds," "Public dogs" and "passionless mongrels." Langland's ominous description of the scene represents significant departure from the painting. Most of the adjectives used in the first stanza are evaluative rather than descriptive which emphasises the presence of the poet's personal vision.

The "deep snow" in line 6 represents hardships experienced by the hunters and the dogs. Despite the fact that the hunters and the hunting dogs are walking home "out of late afternoon ... toward the neutral evening," at a time when the shadows are the longest, they are described as "shadowless" due to the absence of sunlight. It is twilight so that the surface of the Earth is neither wholly lit nor wholly dark. The adjectives used to describe different elements of the wintry scene fit this intermediate stage of light (e.g. neutral, passionless, lovering and sooty). This is the perfect time, the poet argues, "of shape and form." The reference to shape (two-dimensional) and form (three-dimensional) links the poem to the painting as well as fuses two different visual styles together in one scene. Likewise, pure colours are mixed together, which generates colour mixtures such as gray-black-olive, green-dark-brown and gray-green. These colour mixtures, which are often darker than the components separately, serves to reinforce this state of indefiniteness and uncertainty. Another important feature in the poem, though being descriptive of Brueghel's painting, is the avoidance of verb to be and the lexical parallelism based on the use of monosyllabic verbs of motion (e.g. trudge, trail, skate, move, walk, creep, crunch, tip, stalk, slide, fall, perch, slip) and signals of spatial order, "Through deep snow," "Descending from the upper village," "On the mill ice pond," "High 
in the fire-red dooryard," "Near it," "across the valley," "Above the gray-green valley" and "over the snow-capped homes" that take us/readers from one place to another in the wintery scene. However, the poet is keen on reminding everyone that the movement in the scene being depicted is actually a kind of "moving in stillness." The repetition of the adjective Flemish, "Flemish children" and "Flemish cliffs and crags," reflects the poet's knowledge of the culture and geography in the painting and his strong sense of place. He does not attempt to at any moment in the poem to strip the scene depicted in Brueghel's painting of its geographical and cultural context.

A very significant feature of Langland's poetry is the use of music, "Langland has an acute ear for the speech rhythms of the rural Midwest, and music often informs his poems" (Greasley 308). There are five irregular stanzas in the poem. There is no rhyme scheme at all or any consistency in rhythm or line length. However, the poet makes use of metrical parallelism such as alliteration in lines 14 "Scattered and skating", line 21 "Creeps and crunches", line 26 "parents and peasant," etc. The most significant and noticeable of these examples occurs in the last line of the poem where darkness and silence are fused together in one image putting an end to all the activities that were taking place in Brueghel's scene. As Thomas Hardy wrote in Tess of the Durbervilles, "In the twilight of the morning, light seems active, darkness passive; in the twilight of evening, it is darkness which is active and crescent, and the light which is the drowsy reverse" (155). The same is true in the scene depicted by Langland in this poem. Darkness pursues the hunters stealthily until everything is covered by darkness:

Darkness stalks the hunters,

Slowly sliding down,

Falling in beating rings and soft diagonals.

Lodged in the vague vast valley the village sleeps.

The last line contains an example of consonance. There is the use of phonemic parallelism in the repetition of the voiced labiodental fricative $/ \mathrm{v} /$ sound from "vague" to "vast" to "valley" to "village." This line represents the final image of the "valley" and the "village" completely embraced by darkness and silence. The consonance between the two helps to connect them aurally. It is in the final stanza that one can reach an understanding of Langland's poetic vision of the scene. Langland's poem on Brueghel's painting turns the painting from a passive construction of a wintery scene in 1565 into a dynamic extension of the same scene where the hunters and all that lies around them are stalked by darkness and silence or fall into a death-like status as suggested by the image of "The night- 
black raven" that "Weaves a net of slumber over the snow-capped homes" of the village.

\section{William's "The Hunters in the Snow"}

"The Hunter in the Snow," inspired by and named after Brueghel's painting, is one of ten poems written by William Carlos Williams towards the end of his career between 1950 and 1962 each based on a Brueghel painting. According to James A. W. Heffernan, "Williams's poems on these paintings inevitably reflect the ways in which he experiences them: through reproductions that transmit them to his eye or revive them in his memory, through commentaries that purport to explain them" (160). That is to say, Williams takes liberties with the paintings and ignores large portions of their scenes. Right from the beginning, Williams asserts that he is depicting an over-all picture of winter:

The over-all picture is winter

icy mountains

in the background the return

from the hunt it is toward evening

from the left

sturdy hunters lead in. (Williams 5)

According to Grant F. Scott, the title of Williams's poem suggests his concern with stasis, "Williams never attempts to substitute a tale for the visual artwork he surveys" (415). Thus, unlike his predecessors, de la Mare, Berryman and Langland, Williams does not attempt to animate the depicted scene or to predict a future moment, and instead he emphasises its motionless by fixing it in time with words. Along with the title of the poem, the use of words like "picture," "foreground," "in the background," and "from the left" emphasises that the poet is describing a painting rather than an external scene of winter even before the reader comes to the last lines of the poem where the association between the poem and Brueghel's painting becomes crystal clear with an explicit reference to the painter's name. Signals of place used in the poem reflect the poet's interest in the structure of the painting. Williams said openly in an interview, "I've attempted to fuse the poetry and painting, to make it the same thing.... A design in the poem and a design in the picture should make them more or less the same thing" (Sutton 321).

The fact that Williams is describing a painted scene is highlighted by syntactic parallelism in the extensive use of verb to be as a main verb that describes a state rather than an action and the complete absence of the progressive form that describes movement and change. However, in the case of his verbal rendition of 
Brueghel's painting, which apparently has more purpose than mere description, his approach seems more deviant to his original source of inspiration. As noted by Heffernan, Williams's poem, unlike Brueghel's painting, "makes no explicit reference to the hunters' descent, and scarcely any to the meaning of their movement" (165). Instead, Williams reverses the spatial movement in Brueghel's painting. In the poem, Williams moves from the skaters and icy mountains in the background to the return from the hunt and the winter-struck bush in the foreground:

the hill is a pattern of skaters

Brueghel the painter

concerned with it all has chosen

a winter-struck bush for his

foreground to

complete the picture. (Williams 5)

In other words, Williams is aware that the "winter-struck bush," though in the foreground in Brueghel's painting, is mainly used by the painter "to complete the picture" of winter. That is why he tries to put the elements of Brueghel's scene in the order of their visual importance. In Williams's scheme, Brueghel was first concerned with the icy mountains and the skaters before shifting his attention to the hunters who "lead in" from the left. As Christina Giorcelli notes, "Williams restructures the painting along his own sightlines and according to his own peculiar, ichnographically motivated, axes of vision" (200). Thus, Williams's poem is not only a verbal representation of Brueghel's painting but also a careful recreation of the winter scene by means of language to draw attention to the contrast between two groups of people, foregrounding Brueghel's skaters who enjoy winter on the frozen lake in the background and backgrounding the hunters who struggle against winter in a winter-struck bush in the foreground.

The poem is divided into three-line stanzas in which scenes from Brueghel's painting are depicted by means of stylistic deviation. Metrically, the poet experiments with a version of free verse he calls "versos sueltos" ("loose verses"), which makes use of the triadic stanza and a variable foot measure. Graphological deviation indicated by lack of punctuation (commas and periods) and the use of lowercase letters, instead of capital letters, at the beginning of new sentences in the poem results in line breaks that occur mid-clause or enjambment (i.e. incomplete syntax at the end of the line) allowing the meaning to run over from one line to the next. Enjambment increases the pace of the poem and leaves it open to interpretation. For example, line two is an example of a common form 
of enjambment "in which the end of one line and the beginning of the following one belong to different phrases, but are part of the same clause" (Leech, $A$ Linguistic Guide, 125). The line introduces the noun phrase "icy mountains" but the reader gets nothing and must continue on to the next line where the spatial relation between the "icy mountains" and other elements in the scene is indicated by the adverb phrase of place "in the background." Throughout the poem, the presence of the stative verb to be is felt both explicitly (used five times as a main verb) and implicitly in cases of ellipsis where it becomes clear to the reader that the missing verb is verb to be, yet it is so obvious that it is avoided, e.g. "icy mountains [are] in the background" and "the inn-sign [is] hanging from a broken hinge" (Williams 5). The absence of a linking verb (to be) that connects the subject "icy mountains" in line two to its adverbial predicate "in the background" in line three as well as the absence of punctuation to determine the relation between the adverb phrase, "in the background," and the following noun phrase, "the return," are examples of syntactic deviation that allows, as Wyatt argued, for many spatial relations to exist between different elements in the picture.

"In the background," sandwiched between the mountains and "the return," now becomes foreground. Does the phrase in fact refer only to the location of the return? Common sense links it with the position of the mountains, while lineation connects it with this now visible activity. (253)

Also, many line-divisions between subjects and predicates throughout the poem achieve creative rhyme schemes as in (return/lead in), (cold/beyond), and (painter/picture). To sum up, Williams's poem is his attempt to describe the composition of the scene in Brueghel's painting. That is why Williams's poem is short and simple as it lacks many of the specific visual details in the painting. His main focus in the poem is to provide an explanation not of its meaning for "Williams passes no judgment, points no moral, draws no inference" (Braider 146) but of its construction. In doing so, Williams highlights through language what was happening in the scene immediately before its completion. The poem provides Williams's own speculation about the work's creation and the painter's artistic choices.

\section{Stevenson's “Brueghel's Snow”}

In her poem "Brueghel's Snow," Anne Stevenson adopts a different approach to Brueghel's painting as she includes herself in the scene and puts herself into a state of questioning about what she sees happening. Stevenson starts the poem with a description of the foreground of Brueghel's painting as indicated in the use of the proximal deictic expression "here" at the beginning of the poem: 
Here in the snow:

three hunters with dogs and pikes

trekking over a hill,

into and out of those famous footprints -

famous and still. (Stevenson 25)

The word "here" refers to a location relative to the speaker and indicates active participation in the scene. In this way, Stevenson (presumably the speaker of the poem) walks into that wintery world she is describing. In the snow, she sees three hunters making their own way slowly or with difficulty as the verb "trekking" in line 3 suggests. The footprints of the hunters, clearly visible in the heavy snow, are described at the end of the first stanza as "famous and still." The description of the hunters' footprints, along with the title "Brueghel's Snow," links the poem and the painting. The hunters' footprints draw their fame and stillness from Brueghel's painting. The word "snow," used in the title to refer to the whole wintery scene portrayed by Brueghel, is also suggestive as it is the chief physical sign of winter in the Netherlands. In this sense, snow is a synecdoche in which a part is taken for the whole. Also, the genitive construction "Brueghel's Snow" involves two nouns, the head "snow" and the possessive determiner "Brueghel's" that modifies the head. In other words, Brueghel's snowy scene in 1565 is of special significance. Commenting on the influence of the historical events in the $16^{\text {th }}$ century on Brueghel's painting (which in turn appear in Stevenson's poem), Michael Jackson wrote:

1565, the year Brueghel painted The Hunters in the Snow was particularly bad and epidemics swept the land. Brueghel's vivid depictions of death and of hell must surely have come from direct personal knowledge of the rape, killing, and pillaging that swept the Flemish countryside during this period. (181)

From the first stanza, it is apparent that Stevenson's experience of the painting is being transmitted to the reader in a more or less conventional syntax and rhyme. Although some of the lines in the first and third stanzas, such as "three hunters with dogs and pikes/trekking over a hill" and "Bent shapes in black clouts, /raw faces aglow/in the firelight, burning the wind," are marked by the ellipsis of the auxiliary verb to be which accelerates the pace of the poem, the syntactic relations between words are self-evident. As for the use of rhyme, the poet employs perfect rhyme in examples like "hill/still/ill/kill" and "snow/show/below/aglow". Elsewhere, she uses half-rhyme, e.g. "pikes/footprints/clouts/stoups," or no rhyme at all. These syntactic and 
phonemic deviations are used by the poet so that the reader can take pauses and think of the word and to reflect that her thoughts about the painting flow more like natural conversation.

The second stanza starts with a rhetorical question "What did they catch?" that is asked (obviously by the speaker) to make a point rather than to elicit an answer since the answer is given directly by the poet "They have little to show." The use of the interrogative form here is an example of stylistic deviation from the declarative and descriptive style employed in the first stanza. It is intended to start a discussion of the contrast between the weary hunters in the foreground and the "delicate skaters below." Here, the adverb "below" is used as a postmodifier of the noun "skaters" to highlight the vertical distance between the two groups. The contrast between the hunters and the skaters is also foregrounded semantically by the use of negative adjectives to describe the hunters such as "little," "bowed," "grim," and "ill." In the village, things are completely different and people, with their faces glowing with warmth or excitement, are in a state of total absence or neutrality to the misery and suffering of the three hunters.

The movement from the foreground to the background is marked by the use of a spatial order signal "In the village" at the beginning of the third stanza. The semantic relation between the hunters and the skaters is again emphasised in this stanza through the use of the adjective "Bent" to describe the skaters which reminds the reader of the adjective "bowed" that was used in the previous stanza to describe the hunters. The word "clouts," used in the third stanza to refer to the clothes of the people of the Flemish village, is "a British dialect word" (Manser 197) meaning winter clothing (as in the old English proverb: ne'er cast a clout til May be out). The word is an example of the use of language that distinguishes the voice of the speaker from a unique culture against the Flemish background and gives the reader insight regarding the culture of the Anglo-American author. The hunters' arrival to their final destination is marked by syntactic parallelism in "The hunters arrive," "pull off their caked boots," and "curse the weather slump down over stoups" which, as the poet suggests, describe actions that could have happened after the moment captured in Brueghel's painting. In this sense, the poet gives the readers that what is being described in the poem is not a painted picture but an event that is going on before her eyes (or perhaps a motion picture).

In the last two stanzas of the poem, Stevenson uses more rhetorical questions. The significance of questions in Stevenson's poetry is highlighted by Emily Grosholz as follows:

Anne Stevenson's poems are full of question marks. No matter what she writes about, she seems to be wondering, perplexed, speculative, 
dissatisfied, because there are so many things she can't pass over, can't not notice, can't forget; so many things that seem impossible in conjunction, and yet there they are. (49)

Asking about "What happens next? In the unpainted picture?" at the beginning of the fourth stanza and "Who's painting them now?" in the fifth stanza, Stevenson is being speculative about the scene. She wants to know what happens next to the hunters in the painting, who is painting such moments now and what has survived from this scene that took place four hundred years ago:

Who's painting them now?

What has survived to unbandage

my eyes as I trudge through this snow,

with my dog and stick,

four hundred winters ago? (Stevenson 25)

The transitive verb "unbandage," along with its object "eyes," is used metaphorically by the poet to reflect a desire for illumination. Accordingly, the poet encourages the readers to enquire not only about the scene depicted in the painting many years ago but also about its present. The fact that Stevenson ends her poem asking about an "unpainted picture" draws attention to Murray Krieger's argument about the possibility of fictive ekphrasis or "an illusion of ekphrasis":

The claim of naive imitation no longer applies, not even in a genre like ekphrasis, which seems to have been created expressly for mimetic purposes. The genre is thus used to allow the fiction of an ekphrasis, a make-believe imitation of what does not exist outside the poem's verbal creation of it. Literal ekphrasis has moved, via the power of words, to an illusion of ekphrasis. The ekphrastic principle has learned to do without the simple ekphrasis in order to explore more freely the illusionary powers of language. (18)

Giving many questions to which the reader attempts to find answers, the poem allows Stevenson to ponder about what does not exist in the original painting and produce an illusion of ekphrasis.

\section{Conclusion}

Based on the stylistic analysis of de la Mare's "Brueghel's Winter," Berryman's "Winter Landscape," Williams's "The Hunters in the Snow," 
Stevenson's "Brueghel's Snow" and Langland's "Hunters in the Snow: Brueghel," all based on Brueghel's painting Hunters in the Snow, many points can be established regarding the earlier questions about the relation between the poems and the painting and the different approaches adopted by the poets in terms of meaning and style.

It is now clear that these poems on Brueghel's painting are not mere literal ekphrases of the painting. They are intended by their writers to be personal reflections rather than impersonal descriptions of the painting. Therefore, certain aspects of the original painting have been foregrounded as well as given a personal and sometimes a historical context. Each poet employs foregrounding to emphasise a particular theme in the painting and to imply a meaning that becomes either part of the poem's vision or even refers to something outside the poem. Indeed, all the poets represent a significant departure from the meaning and context of their source of inspiration. De la Mare's meditative poem serves to reflect the poet's undefined sense of mystery and unease in the early years of the twentieth century. De la Mare speaks of it interpretively and implies a transcendent reality or a spiritual quest that is wholly independent of the material universe portrayed in the painting. Berryman's adds a new historical context to the painting placing Brueghel's scene in the world of WWII. Langland's poem represents his mature philosophical reflections on Brueghel's painting as it becomes stalked by darkness and silence and all its elements fall into a deathlike sleep. Williams's poem focuses on the structure of the painting at the expense of its meaning and context, providing a recreation of the painting rather than a detailed description of it leaving it open to interpretation. Stevenson's, emphasising the special significance of Brueghel's wintery scene in 1565, speculates about its future. She includes herself in the painting and puts the readers in an inquisitive stance about the painted and the unpainted. Thus, the poems are not simply objective verbal accounts of the work of art. Instead of making conclusions about what the painting means, each of the poems presents a unique poetic response to the painting and each of the poets warps the scene depicted to subjective ends.

In terms of style, the parallelism between the titles of the poems and the title of the painting reveals each poet's approach to the painting and indicates something of what they have particularly chosen to foreground or ignore. A key stylistic difference between the poets in their poetic responses to Brueghel's painting is the spatial order each of them used to describe the winter scene. Whereas De la Mare, Berryman and Williams started with a description of the background (icy landscapes) and then moved to the foreground (the return from the hunt), Langland and Stevenson moved from the foreground to the background. The poems also reflect different authorial styles: De la Mare's use 
of negative adjectives, archaic diction and traditional rhyme; Berryman's use of dynamic verbs, progressive forms, future forms and one-sentence structure; Langland's use of compound adjectives, noun adjuncts, colour constructions, monosyllabic verbs of motion and signals of spatial order; Williams's preference of a mixture of stative verb to be and verbless poetry form, loose verses, lack of punctuation, and lowercase letters; and Stevenson's use of rhetorical questions and conventional syntax and rhyme. The poems vary in length (De la Mare's 122 words, Berryman's 196 words, Langland's 296 words, Williams's 94 words, and Stevenson's 124 words) and structure (De la Mare's quasi-Petrarchan sonnet, Berryman's five five-line unrhymed stanzas, Langland's irregular stanzas, Williams's triadic stanzas, and Stevenson's five five-line half-rhymed stanzas). Apart from de la Mare and Stevenson who are traditional and conservative in form and rhymes, the other poets are varyingly modern and experimental.

\section{Endnote}

${ }^{1}$ Hunters in the Snow by Pieter Brueghel.

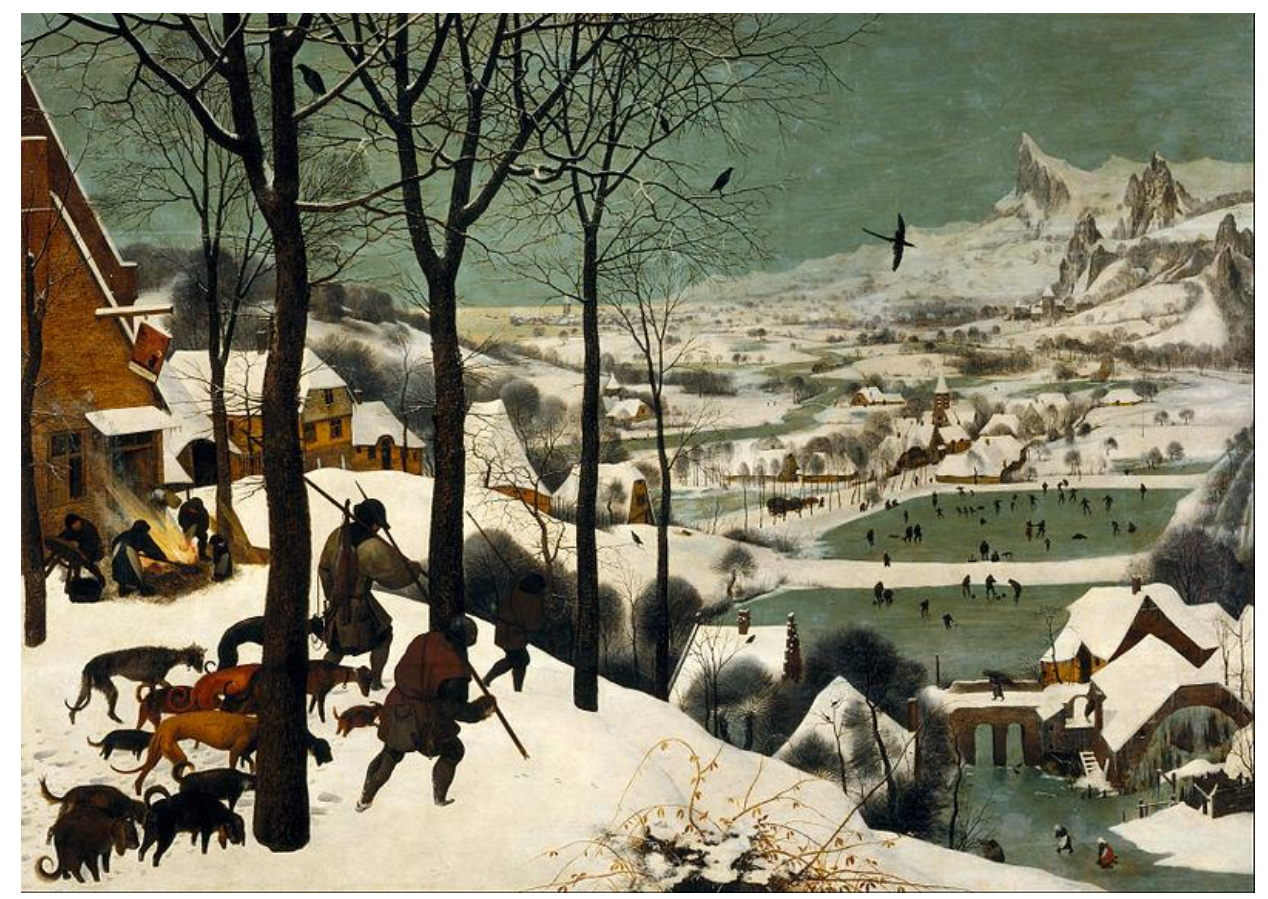




\section{Works Cited}

Barry, Peter. "Contemporary Poetry and Ekphrasis." The Cambridge Quarterly, Vol. 31, No. 2, 2002: 155-165.

Berryman, John. Collected Poems, 1937-1971. Ed. Charles Thornbury. New York: Noonday, 1989.

-----. "One Answer to a Question." The Freedom of the Poet. Toronto: McGraw-Hill, 1976.

Boam, Paul, and McCann, Hugo. "The Painter and the Poet: An Aesthetic Duo in The Classroom." A paper presented at the 2001 AATE/ ALEA Joint National Conference, 12- 15 July 2001. wwwfp.education.tas.gov. au/English/hugopaul.htm. Accessed 20 Oct. 2017.

Braider, Christopher S. "The Art of the Ambidextrous: The Fall of Icarus, The Death of Allegory, and the Meaning of Spatial Realism in the Light of William Carlos Williams's Pictures from Brueghel." Stanford Literary Review 4 (1987): 143- 174.

Brueghel, Pieter. Hunters in the Snow. 1565, oil on wood, Kunsthistorisches

Museum, Vienna. www.khm.at/en/collections/picture-gallery. Accessed 12 Jan. 2017.

De la Mare, Walter. Memory and Other Poems. New York: H. Holt, 1938.

Galligan, Richard. "The Eye of the Beholder." Vegetarian Times, No. 132, August 1988: 61.

Gardner, Helen. Art Through the Ages. New York: Harcourt, Brace \& World, 1970.

Giorcelli, Christina. "Williams Carlos Williams' Painterly Poems: Two Pictures from a Bruegel". Word and Image, No. 4, 1988: 200-208.

Greasley, Philip A. Dictionary of Midwestern Literature, Volume 1: The Authors. Indiana: Indiana University Press, 2001.

Grosholz, Emily. "The Poetry of Anne Stevenson." The Way You Say the World: A Celebration for Anne Stevenson. Eds. John Lucas and Matt Simpson. Nottingham: Shoestring, 2003. 48-60.

Hardy, Thomas. Tess of the D'Urbervilles. New York: Broadview, 2007.

Heffernan, James A. W. Museum of Words: The Poetics of Ekphrasis from Homer to Ashbery. Chicago: University of Chicago Press, 2004. Horace. Ars Poetica [Art of Poetry]. The Works of Horace Translated Literally into English Prose. Trans. C. Smart. New York: Harper \& Brothers, 1894. Jackson, Michael. The Other Shore:Essays on Writers and Writing. California: University of California Press, 2013.

Jarrell, Randall. "Fifty Years of American Poetry." No Other Book: Selected Essays. New York: Harper Collins, 1999.

Kleiner, Fred S. Gardner's Art through the Ages: Renaissance and Baroque. 
Massachusetts: Cengage Learning, 2015.

Krieger, Murray. Ekphrasis: The Illusion of the Natural Sign. Baltimore: Johns Hopkins University Press, 1992.

Krishnamurthy, Sarala. "A Stylistic Analysis of the Story Element in Ngugi's

A Grain of Wheat." Reading Contemporary African Literature: Critical

Perspectives. Eds. J. K. S. Makokha and Reuben Makayiko Chirambo. New

York: Rodopi, 2013. 49-68.

Langland, Joseph. Selected Poems. Amherst: University of Massachusetts Press, 1992.

Leech, Geoffrey. Language in Literature: Style and Foregrounding. New York: Routledge, 2014.

-----. A Linguistic Guide to English Poetry. New York: Routledge, 2014.

Leech, Geoffrey N. and Short, Michael H. Style in Fiction. London and New York: Longman, 1981.

Lessing, Gotthold Ephraim. Laokoön oder Über die Grenzen der Malerei und

Poesie [Laocoon: An Essay Upon the Limits of Painting and Poetry]. Trans.

Ellen Frothingham. Boston: Roberts Brothers, 1887.

Malam, John. Pieter Brueghel. Minnesota: Lerner, 1999.

Manser, Martin H. The Facts on File Dictionary of Proverbs. New York: Infobase, 2007.

McIntyre, Daniel and Jeffries, Lesley. Stylistics. Cambridge: Cambridge University Press, 2010.

Meyers, Jeffrey. "Brueghel and John Berryman." Style, Vol. 49, No. 4, 2015: 470-476.

Plutarch. De Gloria Atheniensium [On the Glory of Athens]. Moralia, 347C, Vol. IV. Trans. F. C. Babbitt. Cambridge, Massachusetts: Harvard University Press, 1936.

Potter, Polyxeni. Art in Science: Selections from Emerging Infectious Diseases, Centers for Disease Control and Prevention. New York: Oxford University Press, 2014.

Scott, Grant F. "Ekphrasis and the Picture Gallery." Advances in Visual Semiotics: The Semiotic Web 1992-93. Eds. Thomas A. Sebeok and Jean Umiker-Sebeok. Berlin: Walter de Gruyter, 1994. 403-22.

Semino, Elena. Corpus Stylistics: Speech, Writing and Thought Presentation in a Corpus of English Writing. London and New York: Routledge, 2004.

Short, Michael H. Exploring the Language of Poems, Plays and Prose. London and New York: Longman, 1996.

Sitwell, Osbert. "On the Relationship between Poetry and Painting." The Burlington Magazine for Connoisseurs, Vol. 78, No. 455, Feb. 1941: 47-49. Stansbury-O'Donnell, Mark. Looking at Greek Art. Cambridge: Cambridge 
University Press, 2011.

Stevens, Wallace. The Necessary Angel: Essays on Reality and the Imagination. New York: Alfred A. Knopf, 1951.

----. Opus Posthumous. Ed. Milton J. Bates. New York: Vintage Books, 1990. 184-239.

Stevenson, Anne. Four and a Half Dancing Men. New York: Oxford University Press, 1993.

Sutton, Walter. "A Visit with William Carlos Williams". Minnesota Review, 1 April 1961: 309-24.

Ulu, Berkan. "A Stylistic Analysis of Ekphrasis Poetry in English." $P h D$ Dissertation. Ankara University, 2010.

Untermeyer, Louis. Modern British Poetry: A Critical Anthology. London: W.H. Allen, 1960.

Williams, William Carlos. Pictures from Brueghel: And Other Poems. New York: New Directions, 1967.

Wyatt, David M. Completing the Picture: Williams, Berryman, and "Spatial Form." Colby Library Quarterly, Volume 13, No.4, December 1977: 246262.

Zagorin, Perez. "Looking for Pieter Bruegel." Journal of the History of Ideas 64, 2003: 73-96. 